\title{
Tuberculosis (TB) incidence in a cohort of individuals infected with human T-lymphotropic virus type 1 (HTLV-1) in Salvador, Brazil
}

\author{
Maria Fernanda Rios Grassi ${ }^{1,2}$, Normeide Pedreira dos Santos ${ }^{2}$, Monique Lírio ${ }^{3}$, Afrânio Lineu Kritski ${ }^{4}$, \\ Maria Conceição Almeida Chagas ${ }^{2}$, Leonardo Pereira Santana ${ }^{1,2}$, Noilson Lázaro ${ }^{1,2}$, Juarez Dias ${ }^{5}$, \\ Bernardo Galvão-Castro ${ }^{1,2^{*}}$
}

From 17th International Conference on Human Retroviruses: HTLV and Related Viruses

Trois Ilets, Martinique. 18-21 June 2015

Few reports evaluate the association between HTLV-1 and TB in countries where both infections are endemic. The incidence and relative risk of TB in a cohort of HTLV-1infected individuals was estimated from 22 to 2012. Using records from the CHTLV database, the Information System on Diseases of Compulsory Declaration (Sinan) database was searched for TB cases matching each patients' full name, date of birth and mother's full name. Structured Query Language for use in relational databases was used to cross match both registries by employing a "linkage" strategy. TB incidence density (ID) in both seropositive and seronegative HTLV-1 subjects was calculated as the number of new-TB-cases per 1,0 person-years of follow-up. From a cohort of 6,495 patients, 1,711 were infected with HTLV-1. 73 TB cases occurred during the 11-year study period: 33 in HTLV-1-infected patients and 40 in uninfected individuals. The ID for the HTLV-1/TB group was 3.3 per 1,0 person-years and 1.1 per 1,0 person-years in the non-infected individuals. The relative risk for TB in HTLV-1+ group was 2.3 (CI 95\% 1.46 - 3.65). In addition, HTLV-1-infected individuals aged 31 to 50 presented the highest ID (3.4). In this group, the relative risk for TB was 2.6 (CI 95\% 1.2-5.5). HTLV-1 patients with TB were older $(p=0.5)$, had lower educational levels $(p=0.02)$ and presented higher recurrence rates of TB $(\mathrm{p}=0.09)$ than nonHTLV-infected individuals with TB. HIV serology was positive for $6.0 \%$ of individuals infected with HTLV-1 versus $12.5 \%$ of individuals with isolated TB $(\mathrm{p}=0.45)$. Patients infected with HTLV-1 are more susceptible to TB. The

\footnotetext{
* Correspondence: bgalvao@bahiana.edu.br

${ }^{1}$ Centro Integrativo e Interdisciplinar de HTLV (CHTLV), Escola Bahiana de

Medicina e Saúde Pública; Salvador, Bahia, Brasil

Full list of author information is available at the end of the article
}

populations of HTLV/TB co-infected patients and HTLV1 -infected individuals share similar epidemiological features, highlighting the neglected nature of both diseases.

\section{Authors' details}

'Centro Integrativo e Interdisciplinar de HTLV (CHTLV), Escola Bahiana de Medicina e Saúde Pública,; Salvador, Bahia, Brasil. ²Laboratório Avançado de Saúde Pública, Centro de Pesquisas Gonçalo Moniz, Fundação Oswaldo Cruz, Salvador, Bahia, Brasil. ${ }^{3}$ Hospital Universitário Professor Edgar Santos, Salvador Bahia, Brazil. ${ }^{4}$ Programa Acadêmico de Tuberculose, Faculdade de Medicina; Universidade Federal do Rio de Janeiro, Rio de Janeiro, Brazil.

${ }^{5}$ Departamento de Vigilância Epidemiológica - Secretaria da Saúde do Estado da Bahia, Salvador, Bahia, Brazil.

Published: 28 August 2015

doi:10.1186/1742-4690-12-S1-P37

Cite this article as: Grassi et al:: Tuberculosis (TB) incidence in a cohort of individuals infected with human T-lymphotropic virus type 1 (HTLV-1) in Salvador, Brazil. Retrovirology 2015 12(Suppl 1):P37.

Submit your next manuscript to BioMed Central and take full advantage of:

- Convenient online submission

- Thorough peer review

- No space constraints or color figure charges

- Immediate publication on acceptance

- Inclusion in PubMed, CAS, Scopus and Google Scholar

- Research which is freely available for redistribution Submit your manuscript at
www.biomedcentral.com/submit C Biomed Central 